George Thomas

McMaster University, Hamilton

\title{
The Impact of Purism on the Development of the Slovene Standard Language
}

Prispevek obravnava pomembno vlogo, ki jo je igral purizem v razvoju slovenskega knjižnega jezika od začetkov do danes. Avtor se posebej ukvarja z dilemami, ki so nastajale zaradi spreminjajočih se družbeno-političnih okoliščin.

The paper examines the significant role that purism has played from the beginnings of the standardization of Slovene to the present. The author deals in particular with dilemmas that have arisen as a result of the changing socio-political circumstances in which Slovene has found itself.

It is hardly surprising, given the cultural and political history of the Slovene people, that purism should have been such a salient factor in the formation and development of the Slovene Standard Language. The overwhelming presence over many centuries of the German language in Slovene intellectual and everyday urban life on the one hand and more recently the threat of competition from Serbo-Croatian in the fulfilment of many socio-communicative functions on the other can scarcely have failed to leave a profound impact on the linguistic attitudes of the Slovene people. Due recognition of the xenophobic attitudes prevailing at various times during the history of written Slovene is given in such representative works as Lencek (1982), Tomšič (1956) and Toporišič $(1966,1967,1970 a, 1983,1984,1985,1987,1991$, 1993). Furthermore, the struggle to fight off foreign influences is dealt with dispassionately in several special studies: most notably Prijatelj (1924), Goršič (1961-62), Prunč (1967), Jakopin (1968) and Toporišič (1970b, 1981). More controversial have been the anti-puristic work of Urbančič (1972), the second edition of which received a highly critical review by Toporišič in 1977 (reprinted in Toporišič 1987: 171-184), and some unscholarly, puristically inspired treatises (e.g. Gradišnik 1985). Finally, it should be pointed out that in addition to the external threats noted above, standard Slovene has also faced internal pressures, including the absence of a continuous written tradition, extreme dialectal diversity resulting in provincial particularism and polycentric codification, and a sharp contrast between the language of the city and peasant speech. Each one of these pressures has given rise to a reaction which I would describe as essentially puristic, though of Slovene scholars Urbančič (1972: 43-44) is alone in treating them as such. Slovene has also been dealt with in several studies of purism in the Slavic languages as a whole: Unbegaun (1932), Auty (1973), Thomas (1988a). Nevertheless, apart from two short articles (Bajec 1959-60, 1965), there has been no attempt to sketch the overall impact of purism throughout the history of written Slovene. The present paper, which makes no claims to produce any new evidence but employs a theoretical framework which has been elaborated to cover a wide variety of languages (see Thomas 1991), is an attempt to provide just such a sketch. 
In general, purism may be characterized as an attempt to provide a paradigm for the codification of a language which makes assumptions about the acceptability of a given set of linguistic items on the basis of their origin. Purism seeks to close a language to elements from sources deemed unacceptable while keeping it open to acceptable elements. On the basis of the selection of targets we can construct a taxonomy of puristic orientations (Thomas 1991: 75-81). Firstly, a language may be closed to external sources. Such xenophobic purism may be general or - more usually - targetted at loanwords and calques from specific languages. Secondly, purists may seek to orientate a language on an older stage in its development to the exclusion of contemporary elements (archaizing purism), or, conversely, they may wish to exclude earlier elements in favour of stressing the need for reform and renewal (reformist purism). Thirdly, some purists prefer to remain faithful to the language of the people (ethnographic purism), while others seek to hold to the language of an elite (elitist purism). Lastly, as first demonstrated by Brozović (1970: 79), there may be a puristic reaction to the results of puristic intervention (anti-purism). Now let us observe the interplay between these various types of purism in the written history of Slovene, following the periodization provided by Toporišič (1993: 137).

\section{II}

When the first Slovene texts emerge in the middle of the sixteenth century, it is immediately obvious how much the spoken language had been indebted to German. Thus the first Slovene book Catechism composed by Primož Trubar (1508-1586) in 1550 has approximately 135 loanwords from many semantic fields but particularly in the realm of religion and ethics (Toporišič 1991: 21-30). It can be argued that Trubar was doing little more than serving the linguistic needs of the heavily Germanized urban population of Carniola and of Ljubljana in particular (Orožen 1971-72: 140). He certainly expended little effort in finding Slovene equivalents for many of the German protestant terms he used. For Trubar "content and comprehensibility" were more important than "a pure and beautiful language" (Tomšič 1956: 12). Already during Trubar's lifetime, this over-reliance on German loans was criticized by Jurij Dalmatin (1547-1589) and especially Sebastijan Krelj (1538-1567) in the introduction to his Postila, though - as Rigler points out - even Krelj, who came from a much less Germanized area than Trubar, himself uses some German loans such as leben, folk, špajza, štima (Toporišič 1991: 26-28; Tomšič 1956: 13; Rigler 1968: 118-119). One of the first to introduce semantic calques like jezik 'language' based on Latin lingua to replace the German loan špraha was the German-born Hieronymus Megiser (1554/55-1619) in his Dictionarium quatuor linguarum of 1592 (Prunč 1967: 23). German influence was not confined to the lexical sphere: there were also many phraseological and syntactic Germanisms in written Slovene. Adam Bohorič (died 1600) was the first to call attention to such usage as the demonstrative pronoun $t a$ as a definite article in imitation of German der (for its use in Trubar, see Toporišič 1991: 42; for further discussion of its authenticity, see Korošec 1972: 166-168), $s$ with the instrumental to denote the agent of an action, cf. German mit, and the formation of passives with bom not sem, cf. the use of werden with the passive in German (Toporišič 1981: 74), though it is possible that Krelj had also had these factors in mind when he described Trubar's language as "do polu nemški" (in subscribing to this view, Toporišič 1991: 41 disgrees with Rigler 1968). However, a resolution of these problems had to await the Slovene renewal. 
The first systematic attempt to replace German loanwords with genuine Slovene words and borrowings from kajkavian Croatian belongs to the edition of the Gospels by Tomaž Hren (1560-1630), a Catholic bishop operating during the early years of the Counter-Reformation, e.g. dedinja 'inheritance' for erbščina, ljudje etc. 'people' for folk, živlejne, život 'life' for leben, ženitovajne 'wedding' for ohcet (Rigler 1968: 213-4). This wholescale de-Germanization of written Slovene was continued by Janez Schönleben (1618-1681) and Father Hipolit (1650-1722) (Toporišič 1987: 181).

The opposition to unnecessary German loanwords was carried forward by Blaž Kumerdej (1738-1805), who listed them in his unpublished dictionary (Stabéj 1973-74: 252). The other lexicographers of this period Marko Pohlin (1735-1801) (see Pohlin 1781) and Ožbald Gutsman (1727-1790) (see Gutsman 1789) began to introduce loans from other Slavic languages especially Croatian and Czech to supplement the deficiencies of Slovene (Breznik 1967: 125-131). On the other hand, they were both opposed to the introduction of rustic words into the written language (Orožen 1971-72: 141). Not surprisingly, the language was still orientated on German - with the result that Pohlin calqued his grammatical terms on German: samoglasnik 'vowel' for Selbstlauter, skupglasnik 'consonant' for Mitlauter. It is noteworthy, however, that in so doing he did not blindly imitate the word-building constructions of German but frequently replaced a German compound with an adjective + noun phrase, e.g. časna beseda 'verb' for Zeitwort, štivilska beseda 'numeral' for Zahlwort, skupvezliva beseda 'conjunction' for Bindewort (Pirnat 1986: 103-104). This avoidance of compounds has been sustained right into the present century and, as Prunč (1967: 148) claims, appears to some extent to be puristically motivated:

\footnotetext{
Die Resistenz gegenüber den Komposita wird im Slovenischen zusätzlich noch durch puristische Bestrebungen verstärkt, die auch dann noch gegen Lehnübersetzungen dieses Typus ankämpften, wenn sie schon durch die allgemeine Sprachpraxis sanktioniert wurden.
}

\section{III}

With the beginning of the new century we encounter a fresh set of attitudes among would-be codifiers of standard Slovene. Indeed - although this is properly refuted by Toporišič (1987: 181) - Urbančič (1972: 44) goes so far as to claim this to be the true beginning of Slovene purism. Baron Žiga Zois (1747-1819) had called the attention of Valentin Vodnik (1758-1819) to the need to remove unnecessary Germanisms. Vodnik responded by expanding the Slavic sources for the enrichment of Slovene to include Russian to replace Germanisms where no native word existed (Toporišič 1987: 27). Thus in his grammar (Vodnik 1811) the linguistic terminology was systematically based on Russian either in the form of direct loans (cf. glagol 'verb', narečje 'adverb') or calques (cf. glasnik 'vowel' for R glasnoe, soglasnik 'consonant' for $\mathrm{R}$ soglasnoe, vez 'conjunction' for $\mathrm{R}$ sojuz), medmet 'interjection' for $\mathrm{R}$ meždumetie) (Pirnat 1986: 103-104).

As might be expected, urban speech - especially in the Upper Carniolan area - was heavily Germanized. Jernej Kopitar (1780-1844) was the first to confront this Germanization in any systematic way. He pointed not only to the loanwords of writers from Trubar onwards (leben 'life' lebati 'to live'), but also to more covert influences from German (gori jemle for aufnimmt; vunkaj klizati for ausrufen to ex- 
claim'). These influences Kopitar ascribed to the place of German in the education system. He said - no doubt drawing on his own personal experience - of the Slovene-speaking peasant going to receive an education:

\begin{abstract}
Im 8ten oder 10ten Altersjahre hat er den väterlich-Slavischen Herd verlassen, um in der deutschen Stadt von Deutschen in Deutscher Sprache zum Deutschen Staatsdiener erzogen zu werden. Nun muß er seine Slavische Muttersprache, die er ohnehin in diesem Alter noch nicht in ihrer ganzen Fülle besitzen kann, mit Fleiß vergessen lernen, damit ihm hold werde die Herrscherinn Teutona. (Kopitar 1808: 54)
\end{abstract}

Consequently - he said of the would-be author - "da er selbst in den Schulen Deutschen Ideengang bekommen hat, so ist es ihm beynahe zu verzeihen, daß er zufrieden ist, wenn in seinem Krainischen Werke nur kein Deutsches Wort sich findet, und $d a ß$ er gar nicht ahndet, daß es auch einen Krainischen Syntax gebe" (Kopitar 1808: 54-55). This observation - no doubt inspired by his mentor Josef Dobrovský, who had voiced similar cricitisms of the Czech of several of his contemporaries (see Thomas 1978) - led Kopitar to reject the Germanized syntax and lexicon of urbanized speech as a basis for the Slovene standard language.

As one antidote to the effects of Germanization, he recommended would-be writers to have more frequent contact with the simple peasantry. Furthermore, he advocated the teaching of Slovene to enthusiastic pupils from the countryside at the Theological Institute in Ljubljana:

... mit Hülfe solcher Schüler, die, ihrer Bestimmung nach, durch das ganze Land vertheilt sind, würde der Krainische Lexikograph den gesammten Sprachschatz wie mit einem Netze umfangen! Unsere Slavischen Brüder in Ost und Süd, die uns für bereits ganz germanisiert halten, und - wir selbst würden erstaunen über unsern altgeerbten Reichthum! (Kopitar 1808: 56).

It is instructive that Kopitar even employs the ethnographic principle in his treatment of the vexed question of the definite article in Slovene, although, as we shall see he does not quite have the strength of his convictions. He quotes the following categorical statement by Dobrovský in support of his claim that "die slavische Sprache" (i.e., Slovene) has no definite article:

Der Slave kennt keinen Artikel. Germanisierende Dialekte, als der Windische in Krain, und der Wendische in der Lausitz /to which he might have added spoken Czech - g.t./ machen hier eine Ausnahme, und verläugnen dadurch ihre echt Slavische Abkunft (Dobrovský 1792: 14; I have left the quotation as it appears in Kopitar although the original differs in several insignificant details).

But what then is one to make of a "Stock-Krainer" who asks of another: "Ktiro kravo si drajži prodal, to pisano al to černo?" Is this not really an article, Kopitar asks rhetorically. (Kopitar 1808: 215). Incidentally, Kopitar makes a further telling observation at this point, namely that "Nicht der Dialekt, nur unsre ungeweihten Schreiber germanisiren". This is a common tactic among purists: to castigate individual or group performance rather than admit to some deficiency in the language itself, but it allows Kopitar to direct blame on the lack of institutions for instilling proper instruction in the Slovene language. 
With Kopitar, then, began the search for ljudskost (for more on this concept, see Lencek 1982: 276-278), that ethnographic orientation, which has been a potential constituent of Slovene purism right up to the present day (see below). However, in contradistinction to Serbian ethnographic purism, this viewpoint, which stemmed from the whole new cultural paradigm of Romanticism and the newly evolving interest in the unaderaltered language of dialects on the part of Jakob Grimm and his followers (Orožen 1971-72: 142-143), was never to become the sole puristic orientation in Slovenia.

Kopitar also explicitly recommended as part of his de-Germanization programme "Lectüre in solchen Slavischen Mundarten, die von Deutschland nichts wissen können" (Kopitar 1808: 56). Consequently, when, like many Slovenes before him, he sought enrichment from other Slavic languages it was with the important proviso that these should be Slavic languages which themselves had escaped the impact of German (Tomšič 1956: 19-20). Had this lead been followed, any influence from the two most easily accessible Slavic languages, Croatian and Czech, would have been effectively blocked. However, Kopitar's espousal of the so-called Pannonian theory of the origin of Old Church Slavonic did at least mean that elements of Church Slavonic could be legitimately added to the list of potential indigenous sources of enrichment for the Slovene lexicon. This opened the way to the archaization of written Slovene, which, as we shall see was taken up as another of the main threads of Slovene purism throughout the nineteenth century. Thus, the net result of Kopitar's reforms - far from from bringing the written language closer to the spoken form as he intended - would have been, as Toporišǐc (1981: 77) has observed, through archaization, ethnographization, de-Germanization and Slavization to take it further away from the relatively stable koine in use throughout Carniola.

This ideational conservatism of the Metternich era (Urbančič 1972: 43-44) was fundamentally repudiated by the next generation, represented by Matija Čop (1797-1835) and France Prešeren (1800-49). Čop was the theorist of the group which combined at the end of the 1820's to produce Krajnska čbelica, an almanach for the intelligentsia. He rejected Kopitar's ethnographic purism as a basis for a standard language:

\begin{abstract}
Denn die zwei erwähnten Eigenschaften /sc. lexicalische Reinheit und grammatische Richtigkeit/ machen noch lange nicht die ganze Bildung einer Sprache aus. So lange nämlich eine Sprache darauf beschränkt bleibt, die Begriffe des einfachen Landmannes auszudrücken, und nicht geeignet ist, in den höhern Kreisen des Lebens und der Wissenschaft zum Mittheilungswerkzeuge zu dienen, kann sie auf den Namen einer gebildeten nicht wohl Anspruch machen, /den durch bloße Reinheit auch manche Sprachen der Wilden verdienen würden./ Nur dadurch, daß eine Sprache nach und nach in diese Kreise eingeführt wird, kann sie eigentliche Bildung erhalten. Diese Bildung aber fehlt bis nun der krainisch-windischen in einem höhern Grade als irgend einer slawischen ... (Nuovo discaccimento di lettere inutili, das ist: Slovenischer ABC-Krieg, published as a supplement to Illyrisches Blatt 1883, quoted in Pogačnik 1978: 116, 156).
\end{abstract}

The success of Čops conception depended on the existence of a suitable literary model. This fortunately could be found readily to hand in the poetry of Prešeren, his close friend and protégé. Prešeren wanted to Europeanize and de-provincialize 
Slovene language and literature and hence was totally opposed to the confinements of purism (Urbančič 1972: 45). These sentiments he expressed in his satire Nova pisarija with its antipuristic criticism of Ravnikar and Metelko (Toporišič 1987: 62). He was also highly sceptical towards Murkos dictionary (Murko 1833) with it marking of all supposedly non-Slovene words with a cross: "kdor pa bi umel vse nezakrižane besede za slovenske, bi moral biti slep domoljub" (quoted in Toporišič 1987: 63). Although he was critical of unnecessary Germanization as in Murkos dictionary, Prešeren was far from receptive to de-Germanizing purism, fearing lest it should lead to an excessive gap between the everyday colloquial language and the standard (Toporišič 1987: 63). This accords with his own practice, since, according to Prunč (1967: 38), an analysis of the Germanisms in Prešeren's syntax would result in a blood-letting. On the other hand, unlike his contemporaries who had to make use of Croatian and Russian expressions, Prešeren’s poems contained no loanwords (Breznik 1933: 134).

\section{IV}

Still further from Kopitar's ideals were those Slovenes, who in the 30's and 40's became followers of the Illyrian Movement, whose programme called for the Slovenes to give up their standard language in favour of a cooperative effort at first with all South Slavs and finally with Croats alone. However, this movement, which had only ever appealed in any significant numbers to Styrian Slovenes, began to lose its attractions with the switch in 1836 to štokavian away from kajkavian Croatian, which had had the advantage of being genetically close to many of the dialects of Slovene, and with the success of Prešeren in demonstrating the poetic capabilities of Čops conception of standard Slovene. However, the close links with events in Zagreb and the espousal of the ideas of Slavic reciprocity promulgated by the Slovak Ján Kollár provided the right climate for the wholesale adoption of loanwords from other Slavic languages.

Slavization answered the need for the rapid enrichment of the lexicon especially in the intellectual sphere without reversing the prevailing current of opinion against employing loans and calques from German. It remained strong throughout the nineteenth century peaking in waves after 1848 and 1867 (Prijatelj 1924: 49; Breznik 1967: 125-31; Prunč 1967: 49; Thomas 1987; Gadanyi 1992). In theory, any Slavic language could serve as a source of enrichment. In practice, however, Russian, Polish and Czech were by far the most fruitful of these sources (Thomas 1985). In the case of Slovene, Croatian was - quite apart from the impact of the Illyrian Movement among Slovenes - the most accessible idiom and, therefore, was the logical choice to play a key role in the Slavization process (Prijatelj 1924: 53; Thomas 1992: 296-297). Some measure of the rapprochement between the vocabularies of Slovene and Croatian during the nineteenth century is provided by the fact that admittedly in a small sample of intellectual terms - the number of common items increased from almost zero to 70\% (Thomas 1993: 59). Indeed, I have demonstrated elsewhere that, largely because of the inroads of Vukovianism in Zagreb philological schools from the 1890's onwards, the Illyrian Movement has actually had greater long-tern impact on the Slovene than on the Croatian lexicon (Thomas 1988b: 160).

This Slavization (or Croatization), which radically changed the complexion of Slovene, was to be seen first in the "Illyrian" (i.e., Croatian and Slovene) dictionary 
of 1846-49 compiled by Josip Drobnič (1812-1861), who advocated in an article in Slovenija of 13 April 1849 , p. 81 that Slovenes and the Illyrians (i.e. Croats) should come to a mutual agreement on accepting new words for scientific terminology (Prijatelj 1924: 70), and then in the state-sponsored Juridisch-politische Terminologie für die slavischen Sprachen Österreichs: deutsch-kroatische, serbische und slovenische Separatausgabe of 1853 - the Slovene component being the responsibility of Matej Cigale (1819-1889) and Fran Miklosich (Miklošič) (1813-1891). The first full-scale dictionary of Slovene to reflect the Slavization was Janežič (1850-51), which appeared at the peak of a wave of Illyrianism in Slovenia and contains large numbers of Croatian as well as Russian and Czech loans, mostly adopted from Croatian usage. Interestingly, when Janežič came to prepare a second edition in 1867 he chose to leave out the unnecessary loans from Croatian, such as čitati 'to read' (an earlier replacement for brati, a purported semantic calque of German lesen), diviti se 'to be surprised' (for Slovene čuditi se), sličen 'similar' (for Slovene podoben) (Breznik 1967: 126-127). By far the most important lexicographical contribution of this era was that of Matej Cigale, who based his dictionary of 1860 on Vodnik's unpublished manuscript version of 1812 but because of his opposition to coining words he left out all Vodnik's compounds, most of which were clearly calqued on Latin and German, e.g. dušeslovje, dušeznanstvo 'psychology' (cf. $\mathrm{Cz}$ duševěda). However, he was often forced - as in this case - to use instead a loanword (psihologija) or a circumlocutory phrase (nauk od duše) (Suhadolnik 1959-60: 229; for more on on Cigale's paraphrases, see Prunč 1967: 148-149). Cigale also had to submit to using Slavic loans - whether he wished to or not - but for the benefit of the more discriminating reader he flagged such words with crosses or gave their source wherever possible (Suhadolnik 1959-60: 229). As a result, such words as upravljati to manage' from Russian and žrtev 'sacrifice, victim' from Old Church Slavonic were picked up by early prose writers like Josip Jurčič (1844-1881) and Fran Levstik (1831-1887) and passed into active use (Breznik 1967: 127).

\section{V}

Indeed, it would be foolish to ignore the role played by the prose writers and journalists active in the 1860's, 1870's and 1880's in introducing words of their own, in stabilizing usage and in establishing linguistic attitudes. Levstik, for example, was the first to work hard to get rid not just of German loanwords (both in the vernacular and literary usage) - replacing them with Slovene words (for examples, see Korošec 1981: 356) - but also the less obvious symptoms of Germanization in the sphere of word-formation (and not just individual words but whole patterns), word order (especially the placement of the verb at the end of the sentence) and syntactic parallels (such as the too frequent use of the infinitive) (Toporišič 1984: 884). This drive to purge Slovene of German elements was not motivated simply by the high degree of infiltration of these elements but was a reaction to the Germanizing absolutism of the Bach regime, which was highly inimical to the flourishing of the Slovene standard language in public life. The Slovene cause needed to find sustenance and support from other Slav peoples. It is not surprising, therefore, to find that in his early work published in the weekly Naprej (1863), Levstik was under the influence of a pan-Slavic enthusiasm after his studies in Olomouc and his contacts with Slavs during his stint as librarian in Trieste. This is evident in his constant use of Czech, Russian and especially Serbian and Croatian words (Breznik 1933: 138; Koro- 
šec 1981: 353). He singled out Serbian and Croatian in particular "iz katerega pa tudi lehko zajemljemo besede, kolikor in kadar jih koli hočemo, ako nimamo svojih" (Naprej, 3/VII/1863, 211, quoted with the last three words underlined in Korošec 1981: 354). However, he was totally opposed to the mixing of Croatian and Slovene typical of the artificiality of Stanko Vraz's higher style with its štokavian morphology and lexicon (Prijatelj 1924: 66-67).

At the same time, Levstik, like Cigale and later Pleteršnik, favoured archaization of the phonology and morphology of the Slovene standard in the direction of Old Church Slavonic and Old Slovene (Toporišič 1984: 885-886). This stemmed directly from an espousal of the Pannonian theory, the leading proponent of which was Fran Miklosich, whose lectures Levstik had attended in Vienna, although, ironically, Miklosich himself was opposed to any such interpretation of his ideas (Toporišič 1984: 888). This archaization was to have far-reaching and long-term effects on the Slovene standard language, leading to the reintroduction or reinforcement of weakened or lost features of the contemporary vernacular, e.g. the dual, the supine, the infinitive in $-t i$, the adjective desinences (Lencek 1982: 273-274).

The third component in Levstik's conception was that, like Kopitar before him, he was convinced that the base of Slovene must be the language of the people outside the towns (Tominšek 1910: 3). Thus, Levstik combined within his own linguistic outlook the three dominant strands of Slovene purism of the nineteenth century: archaization, Slavizing targetted xenophobia and ethnographism. Archaization and Slavization dominated in the codification of phonological and morphological norms. Xenophobic purism targetted, on the lexical level, word-building and semantic calques modelled on German as well as loanwords from the same source and, on the syntactic level, the parallels between Slovene and German. Slavization opened up Slovene to systematic and wholescale lexical enrichment from the resources of other Slavic languages as an alternative to the now discredited German model. Ethnographic purism, on the other hand, provided a benchmark for judging the authenticity of syntactic constructions. It is also interesting to observe that Levstik favoured one or other of these partially contradictory puristic orientations at various times in his career and in different literary genres. Thus, for example, his indebtedness to Croatian vocabulary in his early career gives way after 1871 to enrichment from Russian and Old Church Slavonic but on a decidedly smaller scale. In his stories and popular writings he resorted to dialectalisms from Lower Carniola, while in his journalism he preferred Slavisms but rejected any mixed Croatian and Slovene language as practiced by some Styrian writers including those who had founded the influential daily Slovenski narod published from 1868 (Breznik 1933: 138-141). In other words, Levstik adapted his language to suit both stylistic requirements and the comprehension level of his projected audience.

The dominant literary personality of this period, Josip Stritar (1836-1923), held equally firm views on the Slovene standard language. Firstly, he was convinced of the need to preserve Slovene roots and to avoid foreign words where a Slovene word was at one's disposal. He himself practised this form of puristic self-censorship with great thoroughness after 1870 (Breznik 1967: 116) and severely criticized writers such as Jurčič for their overuse of foreign words (Breznik 1967: 119). With respect to Germanisms he went as far as to express a desire "to root out the whole German weed" (quoted in Pogačnik 1985: 77). Moreover, he saw it as one of the duties of 
contemporary linguists like Levstik to find replacements for such barbarisms (Breznik 1967: 119). Yet this did not prevent him from accepting the use of German words which were current in popular speech (Breznik 1967: 117).

In his attitude to Slavization, however, Stritar broke new ground. He did not mind the borrowing of individual words from Serbian and Croatian for which Slovene lacked an adequate equivalent (Breznik 1967: 122 with specific references to Dunajski zvon, 1877: 158) Indeed, he stressed the need for lexical enrichment and recommended the exploitation of the resources of the other Slavic languages, especially Russian, which held a special place in his mind because of the importance of Russian literature (Pogačnik 1985: 77). However, he clearly saw the dangers inherent in the unbridled mixing of these Slavic elements in Slovene prose:

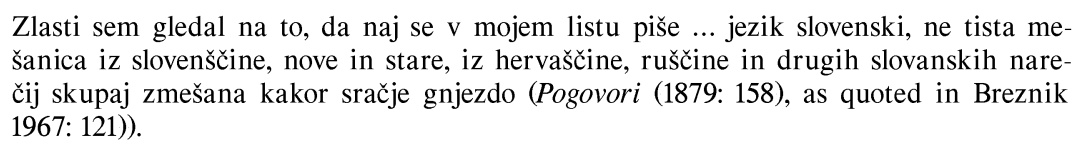

It is important to recognize that Stritar is breaking here not only with the tradition of Slavization but also with the archaizing orientation in Slovene purism. But it was rapprochement with Croatian which was the central target of his opprobrium. Indeed, he went so far as to identify it as one of his four principles of good writing:

Pustimo že vendar tisto neuspešno približevanje k drugim slovanskim narečjem, posebno hrvaščini. Hrvatje naj pišejo hrvaško, mi pa slovensko; saj si vendar lahko ostanemo bratje in se lepo sporazumevamo med seboj. Iz te mešanice ne bo dobrega kruha. In pa tisto novo besedoslovje! (Ljubljanski zvon, 1895: 691 as quoted in Breznik 1967: 122)

Thus, he fiercely condemned the flirtation with Illyrianism exemplified in the Kmetijske in rokodelske novice, edited from 1843 until his death by Janez Bleiweis (1808-1881) (Pogačnik 1985: 77). Stritar’s contribution to the debate marks, therefore, the true beginnings of that anti-Slavic orientation, which was to become such a prominent feature of Slovene purism of the twentieth century. However, one should be careful to distinguish the motivations of anti-Slavic purism in the nineteenth century from its later manifestations. Slavization was effectively taking the Slovene standard language away from its roots and making it less comprehensible to the average reader (this theme is a leitmotiv of Prunč 1967). Moreover, hybridization was robbing the language of the sense of an integrated identity it required to maintain its prestige as a standard idiom. Indeed, not surprisingly, many prose writers towards the end of the nineteenth century preferred, like Stritar and also Stanislav Škrabec (1844-1915), to turn away from these Slavic influences and immerse themselves in peasant speech (Breznik 1967: 121, 128; Tomšič 1956: 25).

Some sense of the contradictory attitudes to Croatian elements during this period can be gleaned from the experience of Jurčič (these remarks are based on Breznik 1933 (1982): 143-146). As editor of the daily Slovenski Narod from 1871 till his death and as one of the first significant prose writers in Slovene Jurčič was in a position to have considerable influence on standard Slovene. At first he joined the Illyrians, but did not use the Croatian words that Levstik and Bleiweis had introduced. Then he turned away from the position of the Croatizers on his own news- 
paper and the Jug group in Vienna, who advocated the use of Croatian in Slovene public life. Yet he worked for some time in Sisak and his use of Croatianisms increased markedly but as he settled back in Maribor his Slovene was purged once more of this influence even though his profound love of the Croatian language remained. A similar scenario was reenacted after his visits to Zagreb in 1872 and Belgrade in 1874. Nevertheless, Jurčič is responsible for introducing several Slavic loans which have remained in active use, e.g. otvoriti 'to open', pokret 'movement', naznačiti 'to designate' (Breznik 1933 (1982): 156).

\section{VI}

As we enter this century, the slim volume entitled Antibarbarus by Jože Tominšek (Tominšek 1910) represents a rare Slovene excursion into a genre which has a long European tradition. If one compares this work with the plethora of brusy in Czech from the end of the nineteenth century, for example, one soon realises the essential moderation of the intensity profile of Slovene purism. This impression is strengthened still further when one examines the content of Antibarbarus. There is no long diatribe against inundations of foreign words or any jeremiad for the decay of the norms of standard Slovene; there is not even a campaign against Serbo-Croatianization. Instead, the book takes cool, measured aim at some of the threats to the well-being of the language. It points out for example (p. 6) that it is unfortunate that the language of Ljubljana has played such a prominent role in the written tradition of Slovene:

... da so si dotični pisci izbrali za svoj organ baš najgrše in najmanj slovensko narečje, namreč ljubljansko, katerega posebnost (premnožica nemčizmov in oškrtanje vseh končnic) se v takih jezikotvorih še nalašč na debelo pretirava. Škoda, da se pisatelji niso odločili za katerokoli čisto, res domače narečje!

But then he does not favour a retreat into the cul-de-sac of ethnographism either:

Dokler pa je narečje le narodna noša za zabavljanje in celo za barabstvo, tako dolgo ne more biti uniforma za veljavnejše slovstvene prikaze (p. 6).

$\mathrm{He}$ asserts that the language of the peasantry and country folk can no longer be a legitimate base for standard Slovene, as advocated by Levstik, since the standard language was now what was taught in schools and appeared in textbooks (pp. 3-4). Moreover, there now existed what was lacking in Levstik's time - a good dictionary in the shape of Pleteršnik (1894-95) (p. 5). The ordinary colloquial language of the intelligentsia - "tisti kompromisni jezik med knjižnim jezikom in narečjem" - also came in for criticism as being the result of the too speedy development of the standard language - "iz kmeta je prehitro postal gospod" (pp. 6-7). Although he saw a positive advantage in the fact that the language was developing (p. 7), he was on his guard against "novotarija, ki je morda celo tujega izvora, ta se mora izganjati vsemi sredstvi” (p. 8).

Tominšek was not opposed in principle to loanwords although he took exception to the overuse of certain suffixes, e.g. $i s ̌ k i$ for adjectives ("zveni čisto po nemško": p. 28) or verbs in -irati ("preveč očiten znak tujstva”: p. 63). He pointed out that resistance to foreign words was dependent on non-linguistic factors: a sympathy 
or antipathy towards the speakers of the language in question (pp. 47-48). The artificial calquing of German placenames like Solnograd for Salzburg, Inomost for Innsbruck, Crni Les for Schwarzwald was to be avoided - "vsa taka samovoljno skovana imena so iluzorna" (p. 49), as was the resurrection of old forms like Vojmir for Weimar (p. 50). One whole section (pp. 8-18) is devoted to a critical examination of syntactic constructions slavishly modelled on German or Italian. However, Tominšek also points out forcefully that a supposed Germanism se gre 'it is a matter of' is in fact no such thing, departing as it does in a crucial way from any of the possible German equivalents (es handelt sich um, es geht um) (pp. 62-63).

In short, this remarkable volume offers a critique of contemporary Slovene usage from a totally apuristic perspective. Moreover, it dismisses, questions, downplays or ignores every one of the puristic orientations encountered in the nineteenth century. As such it augurs well for a dispassionate, apuristic approach to the cultivation of standard Slovene on the eve of the First World War. In his review of Antibarbarus, Anton Breznik (1911), one of the leading scholars to deal with the problem of the history of modern Slovene, concludes that Tominšek is generally on the right lines. However, he notes that in Slovene society there are linguistically enlightened people who have no influence on writers and writers who do not know the details of the language system. As a result:

Po tem potu udere nebroj tujega, zlasti nemškega in italijanskega blaga in se prikrade cela vrsta novih skovank, ki izpodrinejo domače besedne sklade in izraze (Breznik 1911: 36).

What is required for a revival of a sure feeling for grammatical accuracy, which, in his view, had been in decline for the previous two decades, is a change of heart among the linguists "ki se vse premalo mešajo med široke vrste pisateljev in čitajočega občinstva” (Breznik 1911: 35-36).

\section{VII}

In the years since the First World War, the ethnographic and archaizing orientations have rarely been in the forefront of the Slovene puristic debate, which has been dominated by concern with external threats to the well-being of the standard language. Firstly, purists have continued to invoke the spectre of Germanisms, both in the shape of loanwords and calques. Should any of those loanwords which are common in everyday speech be accepted into the standard language? In the case of šank 'tap-room' (cf., Austrian German die Schank), for example, Gradišnik (1985: 176) does not think it acceptable in the standard and suggests točilna miza. Gjurin rightly points that most of them only have a very circumscribed role to play, e.g. cajtenge za gmajn folk (Gjurin 1982: 409). Moreover, a word like ohcet 'peasant wedding' (G Hochzeit) will continue to be an irreplaceable element in Slovene usage, whether or not it is given the imprimatur of linguistic legislators (Korošec 1972: 77). Some purists have continued to call into question certain German calques. For example, Gradišnik (1985: 61, 65, 209) would wish to replace to me čudi 'I am surprised at' (also found in Croatian and based on $\mathrm{G}$ es wundert mich) with čudim se + dative, dopasti se (cf. G gefallen) (although he himself admits it is rooted in the spoken language), zaviseti 'to depend on' (cf. G von etwas abhängen) by biti odvisen. 
Many of these attempts to replace words against which generation after generation of purists has railed have often been in vain. Such is the fate of the so-called Germanism izgledati 'to appear (cf. G aussehen), which, as Prunč (1967: 25) points out, is widespread in everyday usage, has direct parallels in the other Slavic languages and for which there is no obvious Slovene replacement. Secondly, the selection of targets within a given category has been haphazard. In the case of syntactic and phraseological Germanisms, for example, some have been singled out for special attention while others for no very obvious reason have been completely ignored (for examples, see Prunč 1967: 38-40). For others, there have been puristically inspired attempts to show that they are genuinely Slovene, e.g. za vsako ceno 'at any price' (cf. G um jeden Preis) or nimam časa 'I have no time' (cf. G ich habe keine Zeit), which is itself a puristic variant of the vernacular Germanism nimam cajta. It also important to remember that, while German is their probable inspiration in Slovene, both these phrases - like many others - are to be found not only in most of the neighbouring Slavic languages but are international, going back in some instances to classical antiquity (Prunč 1967: 40).

\section{VIII}

A major new ingredient in the puristic mix of the interwar years was the critical stance taken towards Serbo-Croatian elements now that most of the Slovene-speaking territory had fallen within Yugoslavia, where, perhaps not surprisingly, Serbo-Croatian dominated the linguistic landscape as the state and administrative language (Prunč 1967: 123). Indeed, just as the danger of Germanization had finally receded, the threat of Serbo-Croatization took over as the main threat to Slovene linguistic authenticity (samobitnost). As Breznik noted at the time:

Vsako desetletje izgubimo nekaj slovenskih besed in jih nadomestimo s srbohrvatskimi ali tistimi ruskimi in českimi, ki si jih je izposodila srbohrvaščina. (Breznik 1933 (1982): 133)

This threat continued unabated throughout the history of Yugoslavia. Indeed, it is illuminating to compare the dynamics of anti-Serbo-Croatian purism in Slovene with that of anti-Czech purism in Slovak. In the latter case, it reaches an initial peak in the 1930's, burgeons still further during the war years but is decisively muted (i.e. goes underground) during the communist period (Thomas, forthcoming). In Slovene, on the other hand, no such periodization is possible. It makes sense therefore to treat the whole Yugoslav era as a single unit.

The main target were those terms which entered Slovene from bureaucratic usage in the new triune kingdom rather than the huge number of words resulting from the rapprochement with Croatian in the nineteenth century (Thomas 1987: 222-223), though one exception is izvanreden 'extraordinary' removed after the First World War (Prunč 1967: 172). The acceptance of so many Serbo-Croatian words was aided by the fact that a large number of fairly well educated Slovenes have always been bilingual and ready to accommodate to the language of their Serbo-Croatian-speaking interlocutors (Toporišič 1987: 180). Indeed, many an educated person thought he was speaking Slovene when in fact he was using Serbo-Croatian expressions (Breznik 1933 (1982): 133). The campaign to remove Serbo-Croatisms from Slovene was never launched in any systematic way. Perhaps, the fact that, 
whereas the Slovaks had from 1932 onwards a puristically orientated journal devoted to questions of language cultivation (Slovenská reč), the Slovenes had to wait until 1955 for the inauguration of an equivalent publication (Jezik in slovstvo) may have militated against the organization of such a campaign. Even when it did appear, there was no explicit reference to the relationship with Serbo-Croatian in its statement of aims:

Časopis bo skrbel za kulturo slovenskega jezika. Zato bo prinašal članke iz pravorečja in pravopisa, besedotvorja, oblikoslovja in skladnje ... spremljal bo našo govorjeno in pisano besedo ter jo normativno usmerjal, prikazujoč pri tem njeno intimno bistvo, domače prvine, ter svareč pred škodljivimi ali nepotrebnimi tujimi primesmi (Jezik in slovstvo, I (1955-56), 1).

Because of difficulties of identification, purism directed at Serbo-Croatian elements resulted in the removal of Slavicisms in general (Auty 1973). However, as often happens with purist movements, it fought "immer nur gegen einige Wörter, die er nun einmal auf's Korn genommen hatte..., während zahlreiche Entlehnungen vom selben Typus ungeschoren blieben" (Prunč 1967: 50).

A certain scepticism towards Serbo-Croatisms is characteristic of many respectable Slovene linguists of this century, most notably Ivan Prijatelj, Anton Breznik, Jože Toporišič. Indeed, during the 80's the last named became if anything even more outspoken in his condemnation of them as Slovene exasperations with Serb-dominated federal institutions grew in intensity:

In Slovenien wehrte man sich zuerst gegen die Überschwemmung mit sprachlichen Elementen aus dem Serbokroatischen, die allmählich in alle Strukturebenen einsickerten. Danach appellierte man haptsächlich an das Gewissen der die slovenische Sprache im öffentlichen Leben Benutzenden, doch dem Prinzip der Sprachkultur mehr Bedeutung zukommen zu lassen. (Toporišič 1993: 149).

However, compared with the writings of Janez Gradišnik his position is moderate and dispassionate. Gradišnik points to the role of snobbery in supporting the use of loanwords:

Že nekatere srbske ali hrvaške besede, rabljene $\mathrm{v}$ govorici kot citatne besede, se zdijo mnogim Slovencem krepkejše od domačih in pravi okras njihovega izražanja. (Gradišnik 1985: 23)

He also questions the continued need even for certain well established words when a perfectly acceptable Slovene word exists, e.g. obala for breg 'shore', blagostanje for blaginja 'welfare' (Gradišnik 1985: 55-56). Many Serbo-Croatisms have been singled out for criticism in the various editions of the pravopis (Gradišnik 1985; for comparisons of the various editions, see Gjurin 1980). Yet Korošec points out (1972: 35-36, 41) that Slovene has never been less threatened than at present and that puristic activity is now - and in his view - mainly for non-linguistic reasons directed almost exclusively at Serbo-Croatian influence.

On the other hand, there have also been those imbued with the spirit of a common Yugoslav destiny who proclaimed "naj bi slovenščina izločala one besede, ki se povsem razločujejo od hrvatskih izrazov" (Breznik 1933 (1982): 133). This point of view was still being espoused into the 1970's by figures such as Boris Urbančič (1972: 64-65), who drew up a list of pairs consisting of a contemporary, common, 
standard item of non-Slovene origin and a standard but semantically limited and of ten somewhat out-dated item of Slovene origin, e.g. časopis - časnik 'periodical', $i z-$ pit - skušnja 'examination', razlika - razloček 'difference', kolodvor - postaja 'station', where the first item provides a bridge to Serbo-Croatian (Urbančič 1972: 13-14, 17-18, 89-90). Toporišič, himself far from the extremes of purism, rejected this point of view unequivocally:

$\mathrm{V}$ teh stvareh je Urbančič prečesto le antipurist, $\mathrm{v}$ tistem pretiranem pomenu, kot besedi purist on pripusuje pomen: človek, ki s svojimi zelotskimi predlogi za izboljšavo kdaj (ali pogosteje) tudi škodi, kot antipurist seveda z nasprotnim predznakom (Toporišič (1987: 179)

Moreover, he regards Urbančičs comparison of the relationship between Slovene and Serbo-Croatian with that obtaining between other languages and English as specious. Firstly, Slovene is threatened by the fact the differences between the two languages are very small, and secondly, there are strong centripetal forces at work. Sheep, he points out, need to be protected from the wolf, and vegetables from the goat, not vice versa (Toporišič 1987: 179).

\section{IX}

In recent years there has been some concern registered about the number of loans from English. Most vociferous in this regard has been Gradišnik (1985), who claims that "prav te pa nam dandanes najbolj silijo v jezik" (p. 22). He wonders whether a domestic equivalent could be found by the experts for words like infrastruktura, policentrizem, pizza (p. 22), though he also notes with obvious regret the failure of gledalnik, the winning entry in a competition organized in 1981 to find a Slovene word for 'television' (p. 72). He also prefers that if they are to be used that words like blue jeans or show be retained in their original spelling so that they can be more readily identified as foreign rather than be rendered into the Slovene spelling system (p. 22). He reveals that information received by the Jezikovno razsodišče shows that in the last fifteen years, $90 \%$ of the words in the hotel trade and $95 \%$ in the cosmetics industry and sports are of foreign origin (p. 23). Even the cautious Korošec (1972: 122-123) has suggested replacing sendvič with obloženi kruhek (clearly a calque of $\mathrm{G}$ belegtes Brot), and hotdog by vroči kruhek, while leaving koktajl in peace. However, he is quick to point out that the reaction to this influence pales in comparison with the de-Germanization of earlier eras:

Vendar je odpor proti angleškim besedam danes bistveno manjši v primerjavi z nekdanjim odporom proti nemškim, ko se je $\mathrm{v}$ obrambi pred nemščino morala poudarjati reprezentativna funkcija slovenskega jezika in pa njegova samobitnost (Korošec 1972: 98)

\section{$\mathbf{X}$}

The four main currents in Slovene purism can be neatly subdivided into those which are directed at external threats and those which are concerned with internal problems. The xenophobic purism has been concerned principally with influences from those languages which have played a large part in Slovene life: German and Serbo-Croatian. The internally motivated purism has sought at one time or another to influence the standard in the direction of older stages of the language (which 
was held to include Old Church Slavonic) on the one hand and the vernacular on the other. We shall discuss each of these currents in turn before turning to their interaction.

The removal of many German loanwords has distanced the standard language from the vernacular, where many of them are retained as everyday concepts in rural and urban life. This distancing is one of the major components in instituting and maintaining that diglossic state, which - as in Bohemia - is so characteristic of the contemporary language situation. On the other hand, any attempt to purge the standard language of the countless syntactic and phraseological calques based on German models has been largely unsuccessful. This is not surprising when we consider that even in Czech, which - in contradistinction to Slovene - underwent an intense, almost pathological cleansing of such covert influences, the net effect of these efforts has been almost nugatory (Thomas 1996). However, we should not ignore the symbolic function of this de-Germanizing purism. It has helped to maintain a sense of Slovene linguistic identity in the face of severe pressure from the dominant language and culture of central Europe in general and the Habsburg lands in particular.

The main source chosen to replace the lexical Germanisms - the adaptation of numerous loanwords from other Slavic languages - has had the net effect of bringing Slovene somewhat closer, particularly in its abstract vocabulary, to the other Slavic languages of the Habsburg Monarchy. Internally, this has taken standard Slovene further from its co-territorial vernacular. Moreover, because a good proportion of these Slavic loans have come from or via Serbo-Croatian, this Slavization exposed standard Slovene to the charge that it was overly dependent on Serbo-Croatian, a language which always threatened to replace Slovene from the higher social functions from the nineteenth century onwards. With the creation of the triune kingdom and the entrenched privileges within it for Serbo-Croatian it was inevitable that earlier scepticism that Slavization might have gone too far should turn into a desire to reverse the current. In the absence of any systematic study of the de-Serbo-Croatization process, it is premature to attempt to assess its impact on the standard language. Perhaps, now that the pressures on Slovene from that quarter have virtually ceased, a dispassionate examination of this episode in the development of the standard language can at last be undertaken.

Archaization, as we have seen, also pulled the standard away from the vernacular particularly with respect to the orthography and the morphological norms. Moreover, it fostered "a tendency toward hypercorrectness and linguistic pedantry" in Slovene society (Lencek 1982: 274). The archaization has combined with xenophobic purism directed at Germanisms to widen the gap between the standard and the vernacular. In a sense, ethnographic purism together with anti-Serbo-Croatian purism took the standard in the opposite direction and helped to prevent archaization and Slavization going to extremes. Indeed, the creative tension between these two sets of forces has kept Slovene on a path of stable development since the growing pains of the late nineteenth century. Perhaps, this helps to explain why, at all stages in the development of standard Slovene, puristic intervention has remained when compared, for example, with the other Slavic languages of the Habsburg Monarchy - essentially moderate and intolerant of excesses. Moreover, every manifestation of purism has a rational explanation in the extra-linguistic context in which the Slovene standard has developed. 
This article has been an attempt to offer a synthesis of the scholarly contributions to the study of purism in Slovene. It is clear that what is needed now is a series of detailed studies of specific episodes in its history. If this article has provided a framework in which these studies can be conducted as well as a stimulus for more general discussion of this fascinating problem, then its chief aims will have been realized.

\section{References}

Auty, R. The role of purism in the development of the Slavonic literary languages. Slavonic and East European Review, LI (1973), 335-343.

Bajec, A. Rast slovenskega knjižnega jezika. Ljubljana, 1951.

- - Slovanske izposojenke, Jezik in slovstvo, II (1956-57), 145-151.

- - O purizmu in puristih, Jezik in slovstvo, V (1959-60), 129-134.

- - Kako smo Slovenci čistili svoj jezik. In: Jezikovni pogovori, Ljubljana, 1965, 203-208.

Bezlaj, F. Vloga kalkov v slovenščini. Jezik in slovstvo, V (1959-60), 140-143.

Borko, B. Vprašanje srbohrvatskega besedja v slovenskem knjižnem jeziku. In: Jezikovni pogovori, Ljubljana, 1965, 209-214.

Breznik, A. Slovanske besede v slovenščini. Čas, III (1909), 268-280, 315-347.

- - Review of J. Tominšek, Antibarbarus, Ljubljana, 1910. Dom in svet, XXIV (1911), 35-37, 79.

- - O časnikarski slovenščini. Dom in svet, 1933, as reproduced in: Jezikoslovne razprave, ed. J. Toporišič, Ljubljana, 1982, 133-161.

- - Literarna tradicija v Evangelijih in listih. Dom in svet, XXX (1917), 170-174, 225-230, 279-284, 333-347, as reproduced in: Jezikoslovne razprave, ed. J. Toporišič, Ljubljana, 1982, 27-54.

- - Življenje besed. Maribor, 1967.

Brozović, D. Standardni jezik. Zagreb, 1970.

Cigale, M. Deutsch-slovenisches Wörterbuch. Laibach, 1860.

Dobrovský, J. Geschichte der böhmischen Sprache und Litteratur. Prague, 1792.

Drobnić, J. (= Drobnič) Ilirsko-němačko-talianski mali rěčnik. Vienna, 1846-1849.

Gadányi, K. From the history of Slovene 19th-century lexicography. Slovene Studies, XIV (1992), 3-8.

Gjurin, V. Slovenski pravopis 1945. Slavistična revija, XXVIII (1980), 425-445.

- - Socialnozvrstna zaznamovanost besedil v Levstikovem Pavlihi. In: Obdobje realizma. Ljubljana, 1982, 401-417.

- - Slovenščina zdaj. Ljubljana, 1991.

Goršič, F. Purizem in pravniški jezik. Jezik in slovstvo, VII (1961-62), 1, 23-26, 2 , $50-53$. 
Gradišnik, J. O zajemanju doma in drugod. Jezik in slovstvo, III (1957-58), $329-331$.

- - Za lepo domačo besedo: priročnik sodobne slovenščine. Maribor, 1985.

Gutsmann, O. Deutsch-windisches Wörterbuch mit einer Sammlung der verdeutschten windischen Stammwörter und einiger vorzüglichern abstammenden Wörter. Klagenfurt, 1789.

Jakopin, F. O deležu ruskih elementov v razvoju slovenskega knjižnega jezika. Slavistična revija, XVI (1968), 65-90.

Janežič, A. Popolni ročni slovar slovenskega in nemškega jezika. Klagenfurt, 1850-51, 2nd edn.: 1867.

Korošec, T. Pet minut za boljši jezik. Ljubljana, 1972.

- - Jazyková kultura v Slovinsku In: J. Kuchař (ed.), Aktuální otázky jazykové kultury v socialistické společnosti. Prague, 1979, 59-63.

- - O Levstikovem publicističnem jeziku. Slavistična revija, XXIX (1981), 351-371.

Lägreid, A. Die russischen Lehnwörter im Slovenischen (Die in der ersten Hälfte des 19. Jahrhunderts übernommenen Wörter). Munich, 1973.

Lencek, R. The structure and history of the Slovene language. Columbus, Ohio, 1982.

Matl, J. Zur Frage der semasiologisch-kulturhistorischen Erforschung der Lehnund Fremdwörter im Slowenischen. Slavistična revija, III (1950), 313-320.

Modic, I. Vodnik kot jezikoslovec. Dom in svet, XXII (1909), 414-421, 446-453, 495-500.

Murko, A. Slloven fko-Nemfhki in Nem Shko-Şlovenfki Rozhni Befednik kakor se slovenfhina govori na Şhtajerskim, Korofhkim in $v$ Jahodnih stranih na Vogerskim. Graz, 1833.

Orožen, B. Slovenščina na srednji šoli po letu 1848. Jezik in slovstvo, IV (1958-59), 216-221.

Orožen, M. Kultura slovenskega jezika $\mathrm{v}$ zgodovini našega jezikoslovja. Jezik in slovstvo, XVII (1971-72), 139-148.

Pirnat, M. Znanstveni jezik v Vodnikovi slovnici. In: A. Vidovič-Muha (ed.), Slovenski jezik vznanosti 1: Zbornik prispevkov, Ljubljana, 1986, 101-109.

Pleteršnik, M. Slovensko-nemški slovar. Ljubljana, 1894-95.

Pogačnik, J. Bartholomäus Kopitar: Leben und Werk. Munich, 1978.

- - Josip Stritar. Ljubljana, 1985.

Pohlin, M. Tu malu besedishe treh jezikou. Ljubljana, 1781.

Prijatelj, I. Borba za individualnost slovenskega književnega jezika v letih 1848-1857. Časopis za slovenski jezik, književnost in zgodovino, IV (1924), zv. 4, 47-75, zv. 5, 15-67.

Prunč, E. Das innere Lehngut in der slovenischen Schriftsprache: Versuch einer Typologie der Lehnprägungen im Slovenischen. Dissertation, Graz, 1967. 
Rigler, J. Začetki slovenskega knjižnega jezika. Ljubljana, 1968.

Stabéj, J. Vpliv in vrednost Pohlinovega Besedisha. Jezik in slovstvo, XIX (1973-74), $249-55$.

Suhadolnik, S. Cigaletov besednjak. Jezik in slovstvo, V (1959-60), 225-230.

Šolar, J. Sestave s -pis in -pisje. Jezik in slovstvo, V (1959-60), 126-128.

Thomas, G. The role of calques in the early Czech language revival. Slavonic and East European Review, LVI (1978), 481-506.

- - Problems in the study of migratory loanwords in the Slavic languages. Canadian Slavonic Papers, XXVII (1985), 307-325.

- - The slavization of the Slovene and Croatian lexicons: problems in their interrelationship in the nineteenth century. Slovene Studies, IX (1987), 217-225.

- - Towards a typology of lexical purism in the Slavic literary languages. $\mathrm{Ca}$ nadian Slavonic Papers, XXX (1988), 95-111.

- - The impact of the Illyrian Movement on the Croatian lexicon, Munich, 1988. The role of diglossia in the development of the Slavonic literary languages. Slavistična revija, XXXVII (1989), 273-282.

- - Linguistic purism. London/New York, 1991.

- - Ján Kollár's thesis of Slavic reciprocity and the convergence of the intellectual vocabularies of the Czech, Slovak, Slovene, Croatian and Serbian standard languages. Canadian Slavonic Papers, XXXIV (1992), 279-299.

- - Convergent trends in the intellectual lexicon of the Slovene, Croatian and Serbian standard languages in the nineteenth century. Zbornik Matice srpske za filologiju i lingvistiku, XXXVI (1993), 47-60.

- - Towards a history of modern Czech purism: the problem of covert Germanisms. Slavonic and East European Review, LXXIV (1996), 401-420.

- - The development of Slovak purism. To appear in Oxford Slavonic Papers.

Tominec, I. Približajmo knjižni jezik ljudskemu. Jezik in slovstvo, III (1957-58), 346-354.

Tominšek, J. Antibarbarus: studije o napakah in pravilih slovenskega pisanja. Ljubljana, 1910.

Tomšič, F. Razvoj knjižne slovenščine. In: Zgodovina slovenskega slovstva, Ljubljana, 1956, 9-28.

Toporišič, J. Slovenski knjižni jezik. Maribor, Vol. 2, 1966, Vol. 3, 1967, Vol. 4, 1970. - - Življenje in jezikoslovno delo o. Stanislava Škrabca. Slavistična revija, XVIII (1970), 179-217.

- - Slowenisch-deutsche Sprachkontakte, in: Kulturelle und sprachliche Minderheiten in Europa: Akten des 4. Symposions über Sprachkontakt in Europa, Mannheim 1980, Tübingen, 1981, 69-79.

- - Teorija in praksa slovenskega knjižnega jezika v drugi polovici 19. stoletja. Slavistična revija, XXI (1983), 437-456. 
- - Theorie und Praxis der slowenischen Literatursprache in der zweiten Hälfte des 19. Jahrhunderts. Zeitschrift für Slawistik, XXIX (1984), 883-891 (German version of Toporišič 1983).

- - Soziolinguistische Probleme der slowenischen Sprache. Linguistica, XXV (1985), 133-156.

- - Portreti, razgledi, presoje: $k$ zgodovini slovenskega jezikoslovja ob 400-letnici Trubarjeve smrti. Ljubljana, 1987.

- - Družbenost slovenskega jezika: sociolingvistična razpravljanja. Ljubljana, 1991.

- - Enciklopedija slovenskega jezika. Ljubljana, 1992.

- - Die slovenische Schriftsprache des 20. Jahrhunderts. Die Welt der Slaven, XXVIII (1993), 137-160.

Unbegaun, B. O. Le calque dans les langues slaves. Révue des études slaves, XII (1932), 19-51.

Urbančič, B. O jezikovni kulturi. Ljubljana, 1st ed.: 1972, 2nd ed.: 1973, 3rd ed.: 1987.

Vodnik, V. Pismenost ali gramatika za perve shole. Ljubljana, 1811.

Prispelo aprila 1996, sprejeto decembra 1996

Received April 1996, accepted December 1996

\section{Vpliv purizma na razvoj slovenskega knjižnega jezika}

V zgodovini slovenskega knjižnega jezika je purizem igral pomembno vlogo. Usmerjen je bil tako proti zunanjim kot proti notranjim dejavnikom, ki so ogrožali jezik. Od zunanjih sta bila predvsem nemščina, ki je kot dominantni jezik srednje Evrope imela velik vpliv na slovenščino na vseh jezikovnih ravninah, in srbohrvaščina, ki je bila dejansko sredstvo mednacionalnega sporazumevanja v bivši Jugoslaviji. Ksenofobični purizem je izločil iz knjižnega jezika večino nemških izposojenk in jih nadomestil z izposojenkami iz drugih slovanskih jezikov in kalki. Ker je glavnina nemških izposojenk ostala $v$ pogovornem jeziku, se je knjižni jezik oddaljil od pogovornega. Po drugi strani pa je bil poskus izločanja številnih skladenjskih in frazeoloških kalkov iz jezika na splošno neuspešen, vsaj s praktičnega stališča. Kljub temu pa je puristični odziv na te prikrite vplive odigral pomembno simbolično vlogo $\mathrm{s}$ tem, da je utrdil slovensko jezikovno identiteto $\mathrm{v}$ zavesti slovenske jezikovne skupnosti. Besedje iz srbohrvaščine pa je povzročalo posebne zagate slovenskim puristom, ker je v 19. stol. hrvaščina dajala slovenščini sprejemljiva nadomestila za mednarodno in nemško abstraktno besedišče. Pri tem pa je bilo zaradi skupnega položaja v Jugoslaviji in izvorne bližine slovenščine in srbohrvaščine $\mathrm{v}$ praksi pogosto težko $\mathrm{z}$ gotovostjo razlikovati slovensko gradivo od srbohrvaškega. Zato je sistematično in nepristransko identificiranje tega gradiva ostalo naloga, s katero se morajo slovenski jezikoslovci soočiti v obdobju politične samostojnosti. Kar zadeva notranji razvoj, so puristi včasih skušali arhaizirati in slovanizirati pravopis in oblikoslovje knjižnega jezika. To je v določenih jezikoslovnih krogih pospeševalo vzdušje hiperkorektnosti 
in pikolovstva. Po drugi plati pa je struja narodoslovnega purizma, ki se začenja $\mathrm{z}$ vplivno osebnostjo Jerneja Kopitarja, služila kot protiutež arhaizaciji in slovanizaciji, ker je utemeljevala normo knjižne slovenščine na sodobnih narečjih. To osvetljuje dejstvo, da puristično poseganje $\mathrm{v}$ knjižno slovenščino lahko $\mathrm{v}$ glavnem označimo kot zmerno in neobremenjeno s skrajnostmi. Vendar je prav tako jasno, da bo puristični spor, ki se vleče od obdobij Trubarja, Kopitarja, Čopa in Prešerna do danes, ostal pomemben dejavnik tudi $\mathrm{v}$ času, ko se določa vloga slovenskega knjižnega jezika na novem družbeno-političnem prizorišču slovenskega jezikovnega področja.

\section{The Impact of Purism on the Development of the Slovene Standard Language}

Purism has played a significant role throughout the history of written Slovene. It has been directed at both external and internal threats to the language. Chief among the former have been German, the dominant language of the region, which has influenced the Slovene vernacular at all linguistic levels, and Serbo-Croatian, which served as the de-facto idiom of inter-ethnic communication in the former Yugoslavia. Xenophobic purism has succeeded in removing most German loanwords from the standard language and replacing them with loanwords from other Slavic languages and calques. Inasmuch as the majority of the German loanwords have been retained in the spoken vernacular this has had the net effect of distancing the standard language from the respective vernacular. On the other hand, the attempt to remove the numerous syntactic and phraseological calques based on German models has been generally unsuccessful in practical terms. However, the puristic reaction to these covert influences has served an important symbolic function in emphasizing a sense of Slovene linguistic identity in the linguistic consciousness of the Slovene speech community. Serbo-Croatian lexical elements, on the other hand, have posed a particularly intractable problem for Slovene purists. This was primarily because in the nineteenth century the Croatian abstract lexicon played a major part in providing standard Slovene with acceptable replacements for internationalisms and Germanisms. Secondly, because of a common involvement in Yugoslavia and the close genetic relationship between Slovene and SerboCroatian it was often difficult in practice to identify Serbo-Croatian material in Slovene with any degree of certainty. Indeed, a systematic, dispassionate identification of such material remains as one of the many tasks confronting Slovene scholarship in the years of political independence. Internally, purists have at various times attempted to archaize and Slavicize the orthography and morphology of the standard language. This has fostered a spirit of hypercorrection and pendantry in some Slovene linguistic circles. On the other hand, the strain of ethnographic purism, which goes back to the seminal figure of Jernej Kopitar, has served as an antidote to both archaization and Slavization of Slovene by seeking justification for the norms of standard Slovene in the contemporary dialects. This helps to explain why puristic intervention in standard Slovene can be generally characterized as moderate and free of excesses. Nevertheless, it is equally clear that the puristic debate, which has resounded in the times of Trubar, Kopitar, Čop, and Prešeren right down to the present day, will continue to be a significant factor as the Slovene standard language seeks to define its role on the new socio-political stage of the Slovene-speaking territory. 